\title{
EFFICACY OF P 547/17 FORMULATION ON DERMANYSSUS GALLINAE EGGS AND LARVAE
}

\author{
Aleksandar Pavlićević ${ }^{1}$, Ivan Pavlovićc ${ }^{1^{*}}$ \\ ${ }^{1}$ „AVES MIT” LLC, Subotica-Bajmok, Republic of Serbia \\ ${ }^{2}$ Scientific Veterinary Institute of Serbia, Belgrade, Republic of Serbia
}

\section{Abstract}

High reproductive potential and short development cycle, in addition to other factors, enable Dermanyssus gallinae to produce adverse effects in the poultry industry. Not all development stages have the same significance, nor are they equally sensitive to the methods and formulations used for Dermanyssus gallinae control. Laboratory tests were conducted by exposing eggs, larvae and protonymphs to P 547/17 formulation of inert oils (Pulcap). The testing was carried out with $20 \%$ oil-in-water emulsion with short exposure ( $1 \mathrm{~min}$ ), and with 10\%, 20\%, 50\% and 100\% oil-in-water emulsion with continuous exposure. In the first control group, water was used (with continuous exposure), while in the other control group eggs, larvae and nymphs were not treated. We determined that in all cases, eggs were laid in high percentage (89-100\%). In addition to this, in tested liquids, larvae were present in high percentage. They changed into protonymphs (8-89\%). In the conditions of full exposure, where parasitic stages cannot leave the emulsion, P 547/17 in time has complete efficacy on development stages. In short egg exposure, when there is dirt, or on absorbent surface, P 547/17 emulsion cannot control them. However, this drawback is not essential in practical conditions. When applied correctly, P 547/17 formulation is efficient in Dermanyssus gallinae control.

Key words: P 547/17 formulation, efficacy, Dermanyssus gallinae, eggs, larvae

\footnotetext{
${ }^{1 *}$ Corresponding author: dripavlovic58@gmail.com
} 


\title{
EFIKASNOST FORMULACIJE P 547/17 NA JAJA I LARVE DERMANYSSUS GALLINAE
}

\author{
Aleksandar Pavlićević ${ }^{1}$, Ivan Pavlović \\ ${ }^{1}$ „AVES MIT” LLC, Subotica-Bajmok, Republika Srbija \\ ${ }^{2}$ Naučni institut za veterinarstvo Srbije, Beograd, Republika Srbija
}

\section{Kratak sadržaj}

Velika reproduktivna moć i kratak razvojni ciklus, pored ostalih činioca, omogućavaju štetnost Dermanyssus gallinae u živinarstvu. Svi razvojni stadijumi nemaju isti značaj, niti su isto osetljivi prema metodama i formulacijama koje upotrebljavamo u kontroli Dermanyssus gallinae. Laboratorijska ispitivanja izvršena su izlaganjem jaja, larvi i protonimfa formulaciji inertnih ulja P 547/17 (Pulcap). Kratka ekspozicija (1 min) korišćena je za ispitivanje $20 \%$ vodene emulzije, dok je neprekidna ekspozicija korišćena za vodene emulzije 10\%, 20\%, 50\% i 100\% P 547/17. U prvoj kontrolnoj grupi za izlaganje koristili smo vodu (u neprekidnoj ekspoziciji), a u drugoj su jaja, larve i nimfe bile netretirane. Utvrdili smo da se jaja u svim slučajevima izležu u visokom stepenu (89-100\%). Osim toga, u ispitivanim tečnostima larve egzistiraju u velikom procentu i presvlače se u protonimfe (8-89\%). U uslovima pune izloženosti, gde parazitski stadijumi ne mogu napustiti emulziju, P 547/17 vremenom ostvaruje potpunu efikasnost na razvojne stadijume. Kod kratke izloženosti jaja, kada su prisutne nečistoće ili upijajuće površine, emulzija P 547/17 ih ne može kontrolisati. Međutim, utvrđeni nedostaci nemaju presudnog značaja u praktičnim uslovima. Sa pravilnom upotrebom, formulacija P 547/17 je efikasna u kontroli Dermanyssus gallinae.

Ključne reči: P 547/17 formulacija, efikasnost, Dermanyssus gallinae, jaja, larve

\section{INTRODUCTION}

Poultry red mite Dermanyssus gallinae (De Geer, 1778) is the most significant poultry ectoparasite. Its significance in poultry industry arises from its prevalence, degree of control, overall impact on the human and poultry health and the environment, as well as the level of direct and indirect damage. 
High reproductive power and short development cycle result in massive numbers of mites, which, in addition to other factors, have harmful effects of D. gallinae in the poultry industry. High intensity D. gallinae infestations can reach the numbers of 25,000 to 50,000, and in exceptional cases even up to 250,000 mites per hen (Van Emous, 2005). The development of D. gallinae has five stages: eggs, larvae, protonymphs, deutonymphs, and adults (Wood, 1917) (Figure 1 and 2). D. gallinae reproduction occurs in the gonadotropic cycle, and is conditioned by blood consumption (Pritchard et al., 2015). During 12-24 hours after blood consumption, the female will start to lay eggs in hidden places. The size of eggs is usually $400 \times 270 \mu \mathrm{m}$. Females usually lay up to 9 eggs in one batch, with several batches in their lifetime (Nordenfors, 2000). Temperature conditions required for laying eggs range from $5-45^{\circ} \mathrm{C}$, while the maximum numbers of eggs are recorded at $25^{\circ} \mathrm{C}$ and $70 \%$ humidity (Nordenfors et al., 1999).

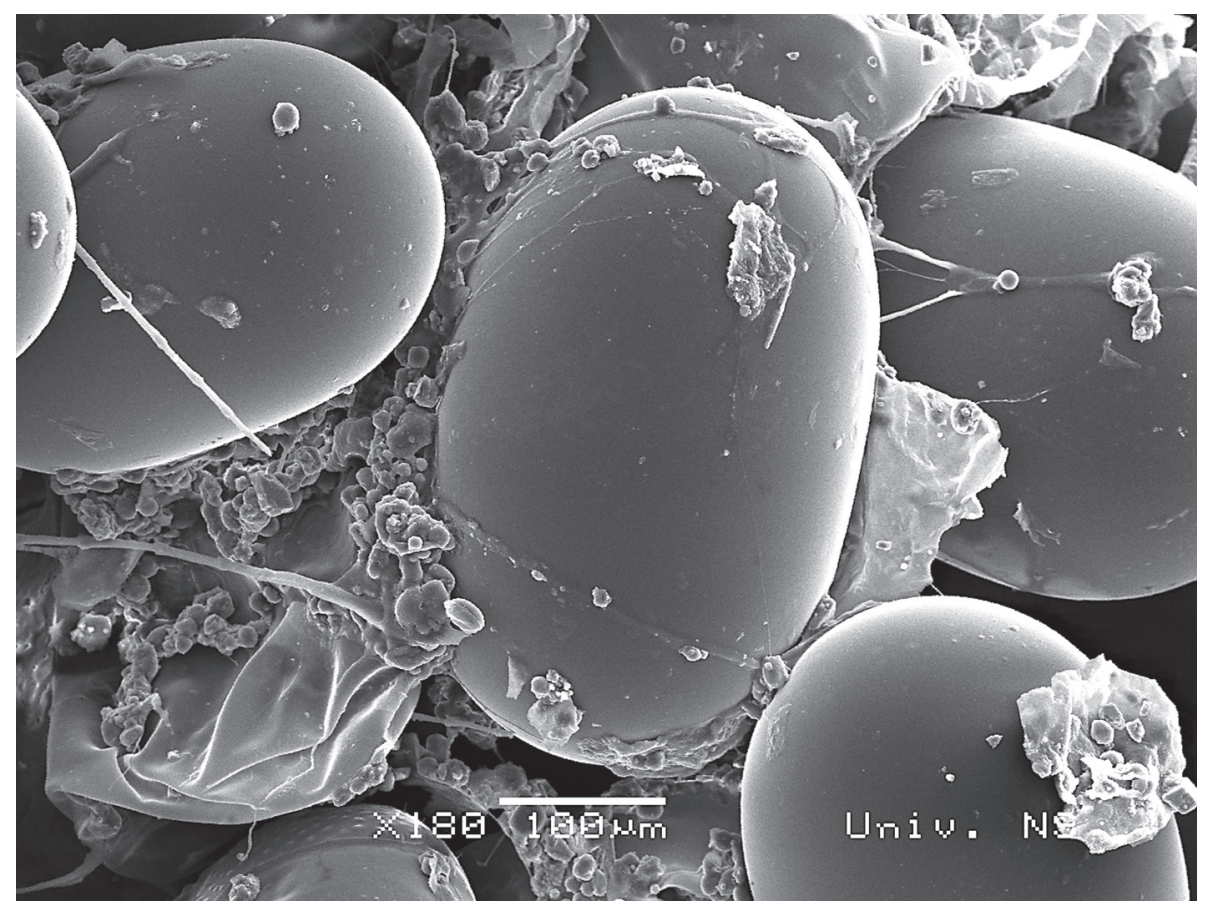

Figure 1. D. gallinae eggs recorded by electron microscope 


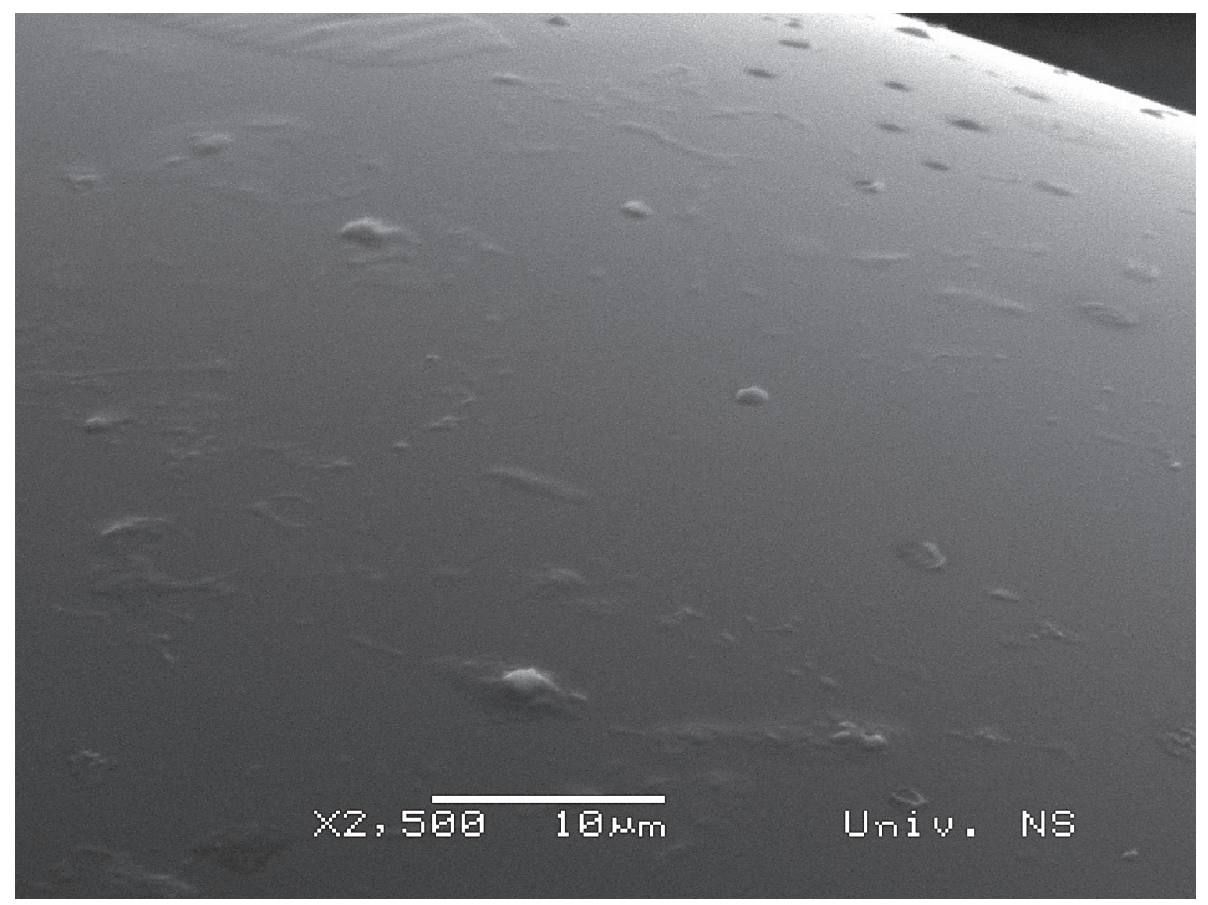

Figure 2. A detail from the surface of D. gallinae egg, recorded by electron microscope

After one to three days, at the temperature of $20-45^{\circ} \mathrm{C}$, larvae are laid from the eggs (Maurer and Baumgartner, 1992; Nordenfors et al.1999). Larvae do not feed. They have 3 pairs of legs. Their colour is seashell white. In the next 1-2 days they change into the protonymph. Protonymphs and deutonymphs have 4 pairs of legs, and in order to transform into the next form, they need to consume blood. In optimal environmental conditions, the development cycle from an egg to an adult can be finished in seven days (Nordenfors, 2000). In practical conditions, this cycle takes longer. For example, at $25^{\circ} \mathrm{C}$, the development of one generation of D. gallinae finishes in 16.8 days (Maurer and Baumgartner, 1992). The tests conducted in Sao Paolo, Brazil, showed that 15 to 42 generations of $D$. gallinae can develop in one year (Tucci et al., 2008).

The control of different development stages can have different impact depending on the species of arthropods.

The aim of our examination was to determine the efficacy of P 547/17 formulation (Pulcap) on the eggs and larvae, and the relevance of the findings for D. gallinae control. 


\section{MATERIAL AND METHODS}

Female D. gallinae fed in isolation chambers in the laboratory, were moved to plastic Petri dishes, in order to lay eggs. The lids of Petri dishes were paired up according to the width and sticked with a duct tape in order to prevent mites from coming out. After the third day, adult mites were removed from the Petri dishes, and the laid eggs were counted and included in the testing.

The first testing group was exposed for 1 minute to the $20 \%$ water emulsion of $\mathrm{P} 547 / 17$ formulation (hereinafter w.e.f.). This was done by first covering the eggs with w.e.f. P 547/17, and after 1 minute, the emulsion was poured out and drained for the next hour. Despite the draining, the Petri dishes still contained a certain amount of leftover water emulsion, i.e. the tested formulation. The testing groups were constantly exposed to $10 \%, 20 \%, 50 \%$ water emulsion, and to the concentrated P 547/17 (100\%) formulation. The testing procedure was also conducted with two control groups: 1. water, with constant exposure and 2. negative control without exposure. The development of eggs, larvae and protonymphs was monitored until the $10^{\text {th }}$ day of exposure $(0-10)$. The temperature in the environment ranged from 19 to $23^{\circ} \mathrm{C}$, and humidity from 49 to $61 \%$.

The results obtained by laboratory testing were interpreted by comparison with the clinical trials of the efficacy of P 547/17 water emulsion.

\section{RESULTS}

Our results are presented in tables 1 to 8 , and figures 2 and 3.

Table 1. Testing 10\% w.e.f. P 547/17, constant exposure.

\begin{tabular}{ccccc}
\hline \multirow{2}{*}{$\begin{array}{c}\mathbf{1 0 \%} \\
\text { w.e.f. P 547/17 }\end{array}$} & $\begin{array}{c}\text { Initial } \\
\text { number } \\
\text { of eggs }\end{array}$ & $\begin{array}{c}\text { Development } \\
\text { stage }\end{array}$ & \multicolumn{2}{c}{ After 10 days } \\
\cline { 3 - 5 } $\begin{array}{c}\text { Constant } \\
\text { exposure }\end{array}$ & \multirow{2}{*}{116} & Eggs & 0 & 0 \\
\cline { 3 - 5 } & & Larvae & 55 & 47.41 \\
\cline { 3 - 5 } & & Protonymphs & 61 & 52.59 \\
\cline { 3 - 5 } & & Overall & 116 & 100 \\
\hline
\end{tabular}


Table 2. Testing 20\% w.e.f. P 547/17, 1 minute exposure.

\begin{tabular}{|c|c|c|c|c|}
\hline \multirow{2}{*}{$\begin{array}{c}20 \% \\
\text { w.e.f. P 547/17 } \\
\end{array}$} & \multirow{2}{*}{$\begin{array}{c}\text { Initial } \\
\text { number } \\
\text { of eggs }\end{array}$} & \multirow{2}{*}{$\begin{array}{c}\text { Development } \\
\text { stage }\end{array}$} & \multicolumn{2}{|c|}{ After 10 days } \\
\hline & & & Number & $\%$ \\
\hline \multirow{4}{*}{1 min exposure } & \multirow{4}{*}{38} & Eggs & 2 & 5.3 \\
\hline & & Larvae & 4 & 10.5 \\
\hline & & Protonymphs & 32 & 84.2 \\
\hline & & Overall & 38 & 100 \\
\hline
\end{tabular}

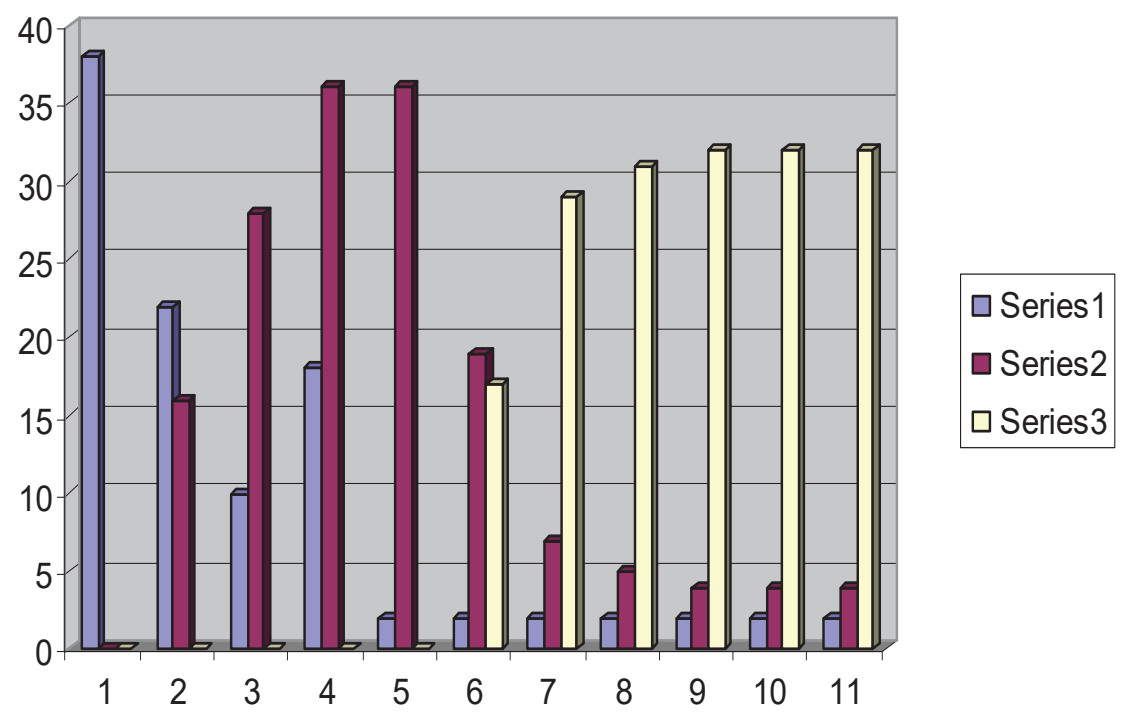

Figure 3. Testing 20\% w.e.f. P 547/17, 1 minute exposure, development of eggs, larvae and protonymphs of D. gallinae presented by days of testing: 1. purple - eggs; 2. maroon - larvae; 3 . yellow - protonymphs.

Table 3. Testing 20\% w.e.f. P 547/17, constant exposure.

\begin{tabular}{ccccc}
\hline \multirow{2}{*}{$\begin{array}{c}\mathbf{2 0 \%} \\
\text { w.e.f. P 547/17 }\end{array}$} & $\begin{array}{c}\text { Initial } \\
\text { number } \\
\text { of eggs }\end{array}$ & \multirow{2}{*}{$\begin{array}{c}\text { Development } \\
\text { stage }\end{array}$} & \multicolumn{2}{c}{ After 10 days } \\
\cline { 3 - 5 } & & Number & $\mathbf{\%}$ \\
\hline \multirow{3}{*}{$\begin{array}{c}\text { Constant } \\
\text { exposure }\end{array}$} & \multirow{2}{*}{108} & Larvae & 3 & 3.70 \\
\cline { 3 - 5 } & & Protonymphs & 72 & 66.63 \\
\cline { 3 - 5 } & & Overall & 108 & 100 \\
\hline
\end{tabular}


Table 4. Testing 50\% w.e.f. P 547/17, constant exposure.

\begin{tabular}{ccccc}
\hline \multirow{2}{*}{$\begin{array}{c}\mathbf{5 0 \%} \\
\text { w.e.f. P 547/17 }\end{array}$} & $\begin{array}{c}\text { Initial } \\
\text { number } \\
\text { of eggs }\end{array}$ & $\begin{array}{c}\text { Develop- } \\
\text { ment stage }\end{array}$ & Number & $\%$ \\
\hline & & Eggs & 10 & 10.31 \\
\cline { 3 - 5 } $\begin{array}{c}\text { Constant } \\
\text { exposure }\end{array}$ & 97 & $\begin{array}{c}\text { Larvae } \\
\text { Proto- } \\
\text { nymphs }\end{array}$ & 7 & 7.22 \\
\cline { 3 - 5 } & & Overall & 97 & 100 \\
\hline
\end{tabular}

Table 5. Testing 100\% w.e.f. P 547/17, constant exposure.

\begin{tabular}{ccccc}
\hline \multirow{2}{*}{$\begin{array}{c}\mathbf{1 0 0 \%} \\
\text { w.e.f. P 547/17 }\end{array}$} & $\begin{array}{c}\text { Initial } \\
\text { number } \\
\text { of eggs }\end{array}$ & $\begin{array}{c}\text { Develop- } \\
\text { ment stage }\end{array}$ & Number & Nor 10 days \\
\hline \multirow{2}{*}{$\begin{array}{c}\text { Constant } \\
\text { exposure }\end{array}$} & 42 & Eggs & 4 & 9.52 \\
\cline { 3 - 5 } & & $\begin{array}{c}\text { Larvae } \\
\text { Proto- }\end{array}$ & 18 & 42.86 \\
\cline { 3 - 5 } & & Oymphs & 20 & 47.62 \\
\hline
\end{tabular}

Table 6. Testing in water, constant exposure.

\begin{tabular}{ccccc}
\hline \multirow{2}{*}{ Well water } & \multirow{2}{*}{$\begin{array}{c}\text { Initial } \\
\text { number } \\
\text { of eggs }\end{array}$} & $\begin{array}{c}\text { Develop- } \\
\text { ment stage }\end{array}$ & Number & After 10 days \\
\hline & & Eggs & 7 & 10.77 \\
\cline { 3 - 5 } & 65 & Larvae & 19 & 29.23 \\
\cline { 3 - 5 } $\begin{array}{c}\text { Constant } \\
\text { exposure }\end{array}$ & $\begin{array}{c}\text { Proto- } \\
\text { nymphs }\end{array}$ & 39 & 60 \\
\cline { 3 - 5 } & & Overall & 65 & 100 \\
\hline
\end{tabular}

Table 7. Control group

\begin{tabular}{lcccc}
\hline \multirow{2}{*}{ Control group } & $\begin{array}{c}\text { Initial } \\
\text { number } \\
\text { of eggs }\end{array}$ & $\begin{array}{c}\text { Develop- } \\
\text { ment stage }\end{array}$ & Number & $\%$ \\
\hline \multirow{2}{*}{ No exposure } & 24 & Eggs & 0 & 0 \\
\cline { 3 - 5 } & \multirow{2}{*}{\begin{tabular}{c} 
Larvae \\
\cline { 3 - 4 }
\end{tabular}} & $\begin{array}{c}\text { Proto- } \\
\text { nymphs }\end{array}$ & 24 & 100 \\
\cline { 3 - 5 } & & Overall & 24 & 100 \\
\hline
\end{tabular}




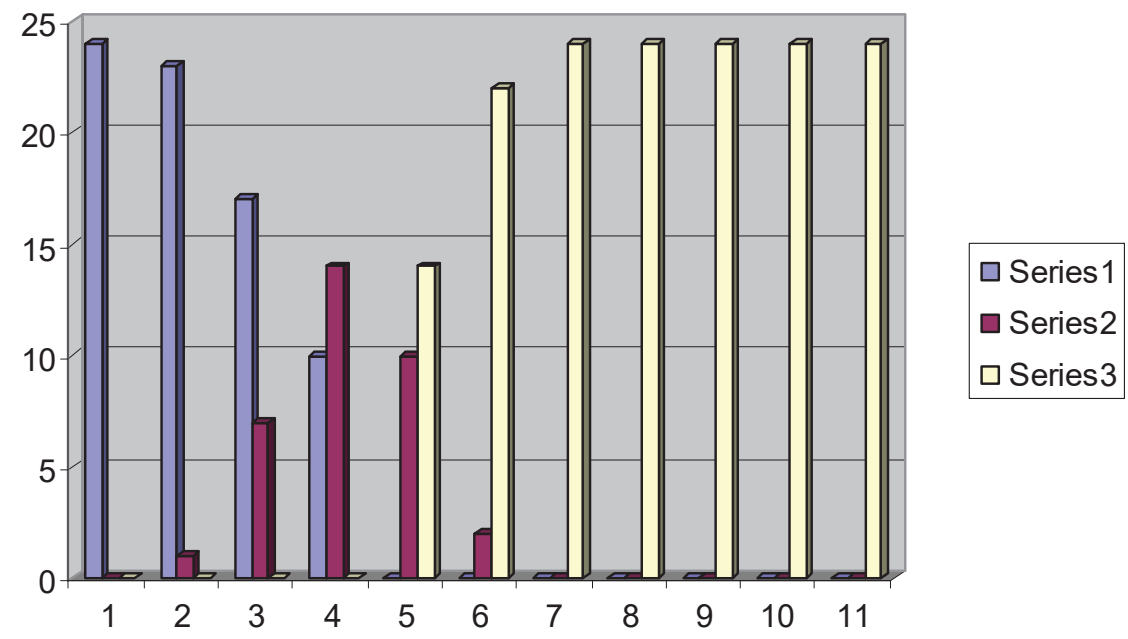

Figure 4. Testing control group, development of eggs, larvae and protonymphs of $D$. gallinae presented by days of testing: 1. purple - eggs; 2. maroon - larvae; 3. yellow protonymphs.

Table 8. Comparative overview of values, percentage of laid eggs and transformed larvae of D. gallinae

\begin{tabular}{lccccccc}
\hline $\begin{array}{l}\text { Percentage (\%) } \\
\text { w.e.f. P 547/17 } \\
\text { and others }\end{array}$ & $\mathbf{1 0}$ & $\mathbf{2 0}$ & $\mathbf{2 0}$ & $\mathbf{5 0}$ & $\mathbf{1 0 0}$ & $\begin{array}{c}\text { Wa- } \\
\text { ter }\end{array}$ & $\begin{array}{c}\text { Con- } \\
\text { trol }\end{array}$ \\
\hline Exposure & $\begin{array}{l}\text { Con- } \\
\text { stant }\end{array}$ & 1 min & $\begin{array}{l}\text { Con- } \\
\text { stant }\end{array}$ & $\begin{array}{c}\text { Con- } \\
\text { stant }\end{array}$ & $\begin{array}{c}\text { Con- } \\
\text { stant }\end{array}$ & $\begin{array}{c}\text { Con- } \\
\text { stant }\end{array}$ & - \\
\hline $\begin{array}{l}\text { Percentage of } \\
\text { laid eggs (\%) }\end{array}$ & 100 & 94.7 & 96.3 & 89.69 & 90.48 & 89.23 & 100 \\
\hline $\begin{array}{l}\text { Percentage } \\
\text { of changed } \\
\text { larvae (\%) }\end{array}$ & 52.59 & 88.89 & 69.23 & 8.05 & 52.63 & 67.24 & 100 \\
\hline
\end{tabular}




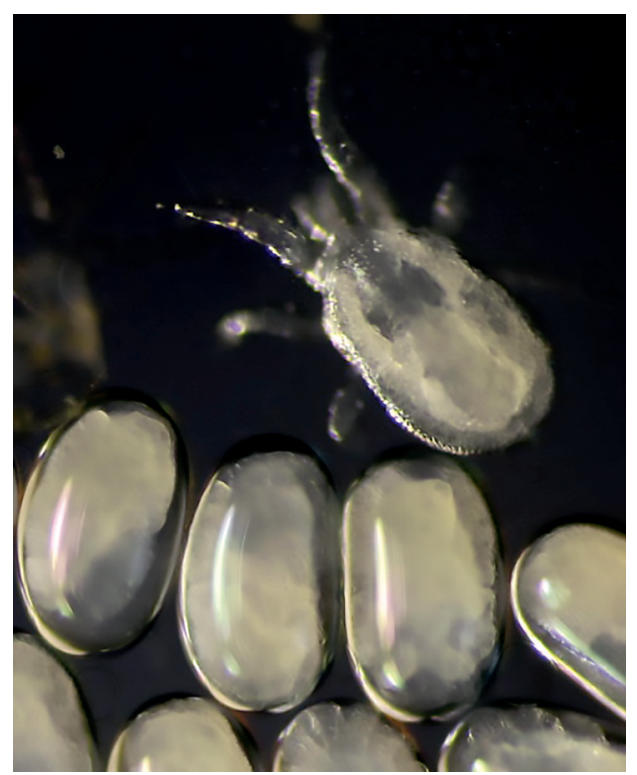

Figure 5. Eggs (with visible embryonic development) and larvae of D. gallinae, in w.e.f. P 547/17, recorded by optical microscope

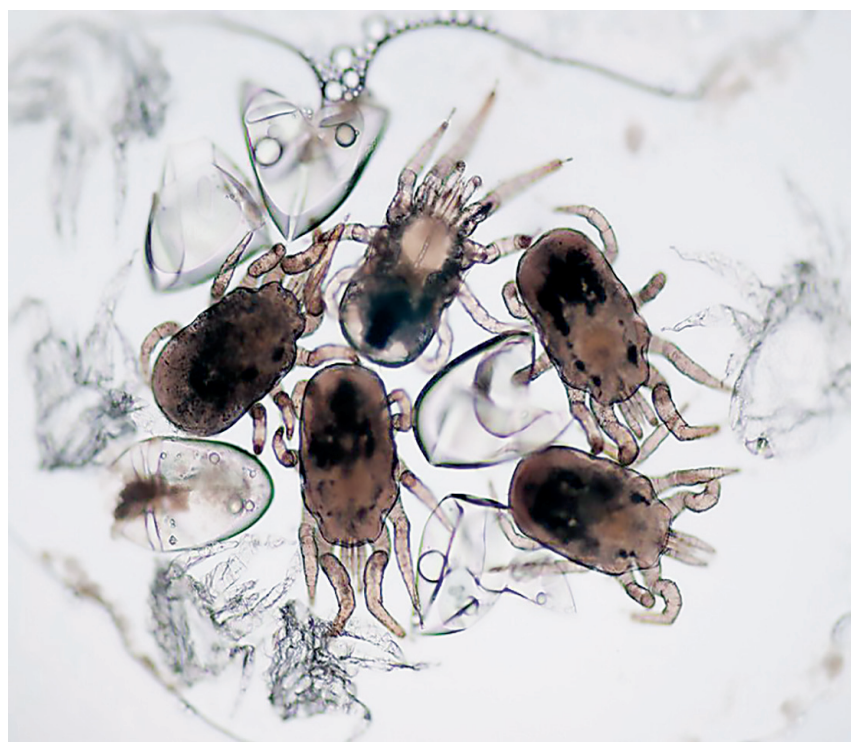

Figure 6. D. gallinae protonymph in w.e.f. P 547/17, recorded by optical microscope 


\section{DISCUSSION}

In untreated, control group, all the eggs transformed into larvae and subsequently into protonymphs. According to the research by Nordenfors et al. (1999), $99 \%$ of eggs developed into larvae at $25^{\circ} \mathrm{C}$, and $92 \%$ of larvae further transformed into protonymphs.

Mineral oils have been used for the control of harmful insects and mites for more than a century (Agnello, 2002). There have been attempts to use various types of oils for D. gallinae control (Guimaraes and Tucci, 1992; Van Emous, 2005; Maurer et al., 2009; Camarda et al., 2018).

Pulcap is the first specialised formulation (P 547/17) and technology (project ID 1115) which uses water emulsion of inert oils for D. gallinae control. The aim is for the biological efficacy of P 547/17 to be thoroughly examined and documented. Preliminary observations from previous tests (Pavlićević et al., 2018) showed that $P$ 547/17 water emulsion in working solutions has no significant effect on D. gallinae eggs.

There is general knowledge about the effect of inert oils. Unlike acaricides and insecticides (in the narrow sense of the word synthetic neurotoxic chemical compounds), oils do not act through specific receptors, but rather in multiple ways. Their effect depends on interaction between physical, chemical, anatomic, developmental and physiological characteristics and behaviour of the targeted mites or insects. The following have been described: affinity to epicuticle, immobilisation (in active stages), preventing respiration, disturbing water balance, penetrating the organism, disturbing cellular functions, etc. (Buteler and Stadler, 2011).

Certain oils are known to have effect on some arthropods' eggs. For example, in insects, Al Dabel et al. (2008) found high efficacy of horticultural oil on Ostrinia nubilalis eggs applied in 3-10\% concentration. Buteler and Stadler (2011) determined that $2 \%$ horticultural mineral oil causes almost total mortality of Choristoneura rosaceana eggs.

Large numbers, short development cycle, i.e. great reproductive capacity of D. gallinae require high efficacy of a formulation used for their control. For direct 1 minute exposure, biological efficacy of formulations for $D$. gallinae control should be $95-100 \%$. If constant and direct exposures are combined, efficient formulations should achieve $100 \%$ efficacy in laborato (ideal) conditions.

The tests were designed to maximise the contact of eggs and larvae with w.e.f. P 547/17 by direct and constant exposure. In spite of this, most eggs underwent their embryonic development smoothly. The degree of egg exposure ranged from 89 to $100 \%$. Larvae existed in the tested fluids in high percentage and changed into protonymphs in $8-89 \%$ of cases. $50 \%$ w.e.f. P $547 / 17$ showed the highest 
degree of efficacy on larval stage where $8 \%$ changed into protonymphs.

There is a significant difference in sensitivity between the development stages of eggs and larvae compared to adult D. gallinae. For adult D. gallinae, 1 minute direct exposure to $10 \%$ w.e.f. P 547/17 would be lethal (Pavlićević et al., 2017). Eggs and larvae were able to withstand, to a high degree, a constant direct exposure to water emulsion $(10 \%, 20 \%, 50 \%)$, even concentrated $(100 \%)$ P 547/17 formulation.

The results of conducted research indicate that eggs and larvae of D. gallinae can stand anoxia. We are not aware of any tests on the anoxia of D. gallinae eggs and larvae. However, hypoxia and anoxia have been indirectly tested in adult $D$. gallinae. Mites were put in Petri dishes, directly exposed to CO2 $(2,500 \mathrm{ppm})$, by spraying for 10 seconds. After 120 hours, the effect of anoxia was $100 \%$ mortality of adult D. gallinae (Kang et al., 2020). Furthermore, we can assume that additional research will find that eggs and larvae of D. gallinae are, to a great extent, not sensitive to controlled $\mathrm{CO} 2$ management.

In comparison, controlled $\mathrm{CO} 2$ management has been used since the 1980s in plant protection in order to control harmful mites (Aharoni et al., 1981). Exposure to $60 \% \mathrm{CO}^{2}$ at $30{ }^{\circ} \mathrm{C}$ results in up to $100 \%$ mortality of adult two-spotted spider mite Tetranychus urticae (Oyamada and Murai 2013). Suzuki et al. (2015) determined that the exposure of eggs and adult females of $T$. urticae and T. kanzawai to anoxia caused by deoxidant over the period of 12 hours at $25^{\circ} \mathrm{C}$ results in up to $100 \%$ mortality.

Laboratory tests were done in the conditions which enable the maximum effect of w.e.f. P 547/17. However, in practical conditions, it is not possible to expose all eggs and larvae of D.gallinae directly, sufficiently and constantly. The reasons for this are mites' way of life on hidden places, limited distribution (overlapping and covered places) of water emulsion in external application by spraying, as well as the very conditions in the poultry industry (absorbent surfaces or presence of dirt). Therefore, in practical conditions, we can expect worse results compared to those found in laboratory tests. Even in ideal laboratory conditions, even with high concentrations, the effect of P 547/17 formulation on $D$. gallinae eggs and larvae did not fulfil the conditions of total efficacy, and should be taken into account. The observed flaw of w.e.f. P 547/17 needs to be overcome by planning the method of application. The choice of method of w.e.f. P 547/17 application starts with the choice of the moment of application. Although w.e.f. P 547/17 can be used in both empty and populated poultry houses, the specific conditions and effects of control will vary significantly.

The development structure of D. gallinae invasion in hosts is reported as $35 \%$ eggs, $10 \%$ larvae, 33\% nymphs and $22 \%$ adults (Van Emous, 2005). In a populated house, w.e.f. P 547/17 is used when necessary. The conditions in a 
populated poultry house are characterised by lack of hygiene, worse distribution of the emulsion due to the presence of poultry (it covers the surfaces) and uninterrupted reproduction of $D$. gallinae (with all development stages present). The efficacy depends on hygienic situation (limited contact and reduced residual effect on surfaces), complexity of environmental conditions, quality of application and intensity and extensity of D. gallinae infestation. In the case of general low intensity infestation, one treatment is implemented, while in the case of general high intensity infestation, there are two treatments. The effects of suppression with w.e.f. P 547/17 in a populated house usually last for 4-5 months.

Formulation P 547/17 is primarily designed for prevention, since this is the primary and essential task of human and veterinary medicine. Treating an empty poultry house with w.e.f. P 547/17 prevents the infestation of a new, young flock of laying hens with D. gallinae invasion (present in the facility).

In an empty facility there is no host (poultry) and therefore no blood which is necessary for laying D. gallinae eggs. Adults will keep the ability to lay eggs for several days after emptying the poultry house, based on the previously consumed blood. At the temperature of $27^{\circ} \mathrm{C}$ and humidity of $80 \%$, egg laying will last for up to 11 days (Tucci et al., 2009). Then it will stop. The development of eggs and protonymphs will be limited to the phase of deutonymph, because from this moment, further development will depend on blood consumption. The absence of blood, i.e. the host (poultry) will prevent further development of protonymphs and deutonymphs. D. gallinae adults remain in an empty poultry house. In some cases, they can endure starvation for more than a year (Pavlićević et al., 2007). Therefore, the success of controlling adults is crucial for the effects which will be achieved in D. gallinae control.

The tests performed in laboratory conditions (Maurer and Baumgartner, 1992 ) indicate that development of eggs into larvae of D. gallinae at $10^{\circ} \mathrm{C}$ lasts for 12 days, while at the temperature of $5{ }^{\circ} \mathrm{C}$ it lasts for up to 50 days or 28.2 days (Nordenfors et al. 1999). In practical conditions, we have not yet found a problem which could arise from a slower development of D. gallinae eggs and larvae at lower temperatures.

Poultry house preparation includes thorough cleaning, washing, deratisation, disinfection and drying. After that, w.e.f. P 547/17 is applied. On unabsorbent surfaces, it has long-lasting, highly efficient prolonged effect even on subsequently exposed mites (Pavlićević et al., 2017). The prolonged effect is especially noticeable in empty facilities, since residual layer is not exposed to dirt or removal.

Favourable hygienic situation, good conditions for the distribution of the water emulsion and sufficiently sensitive development stages of mites, housing down-time (enough time at the temperature conditions in which D. gallinae is 
active), and correct application optimise the efficacy of w.e.f. P 547/17. When these conditions are fulfilled in an empty poultry house, $\mathrm{P} 547 / 17$ results in $D$. gallinae eradication from production facilities, i.e. farms. Eradication has so far been proven in floor housing of parent flocks, cage housing system, conventional and enriched cages for layer housing (Pavlićević et al., 2018; 2019a,b, 2020) in the process of preparation). In aviaries and free range housing, the eradication has not yet been tested. D. gallinae eradication in a poultry house is considered successful if during one year of systematic monitoring, not a single mite is detected. If the conditions are only partially met, P 547/17 results in highly efficient $D$. gallinae suppression. If no conditions are met, $D$. gallinae suppression might not be effective (Pavlićević et al., 2019a).

After comparing the results obtained from laboratory (unsatisfactory effects) and clinical tests (highly efficient suppression and eradication), we believe that the development stages of eggs and larvae are not crucial for $D$. gallinae control. Despite their resistance, the need for feeding and short development period makes them inconsequential for the control procedure. Adult stage is crucial for the control.

In the appendix about the assessment of significance of $D$. gallinae eggs and larvae for the control, there is the research on the efficacy of the formulation of active substance fluralaner (isoxazoline). Fluralaner is administered to poultry per os, in drinking water and it works only on adults and development phases that feed on blood (protonymphs and deutonymphs). Therefore, fluralaner has no effect on eggs and larvae. Nevertheless, the effects of D. gallinae control can last for up to 238 days (Thomas et al., 2017). The development of $D$. gallinae eggs and larvae continues in aquatic environment as well. When washing the poultry house, the water itself (especially on floors) will not significantly affect the vitality of eggs and larvae (apart from mechanical removal). Therefore, they are expected to complete their development after the surfaces dry off (Thomas et al. 2017). However, a detailed washing is a prerequisite for creating the hygienic conditions which enable a quality contact with the water emulsion and prolonged effect on unabsorbent surfaces.

\section{CONCLUSION}

P 547/17 formulation does not have a significant impact on D. gallinae eggs and larvae. Although they have a higher resistance level, eggs and larvae are not very important for D. gallinae control. Adult control is crucial. Intensive and long-lasting prolonged effect of w.e.f. P 547/17 successfully eliminates adults, thereby including all developmental stages. Therefore, P 547/17 achieves a highly effective suppression, and with an optimal application in an 
empty poultry house, it is even able to eradicate D. gallinae from facilities, i.e. poultry farms.

Laboratory and clinical tests, as well as the formulation and application technology make a unique method for D. gallinae control.

\section{Author's contributions}

AP provide the basic idea, coordinated the research and experimental study and processed the results, and IP additionally processed the results of the study and prepared the manuscript

\section{Competing Interests}

The authors declare that they have no competing interests.

\section{REFERENCES}

1. Agnello, A.M. 2002. Petroleum - Derived spray oils: chemistry, history, refining and formulation. In: Spray Oils Beyond 2000: Sustainable Pest and Disease Management. Eds. G.A.C. Beatie, D.M.Watson, M.L. Stevens, D.J. Rae and R.N. Spooner-Hart, University of Western Sydney Press, Australia, 2-18.

2. Aharoni Y., Stewart J.K., Guadagni D.G. 1981. Modified atmospheres to control western flower thrips on harvested strawberries. Journal of Economic Entomology, 74, 3, 338-340. doi: 10.1093/jee/74.3.338.

3. Al Dabel F., Mensah R., Frerot B. 2008. Effects of nC24 and nC27 petroleum spray oils on oviposition and egg survival of Ostrinia nubilalis Hübner (Lepidoptera, Pyralidae) and Trichogramma brassicae Bezdenko (Hymenoptera, Trichogrammatidae) adults on maize plants. International Journal of Pest Management, 54, 1, 5-11. doi:10.1080/09670870701549632.

4. Buteler M., Stadler T. 2011. A Review on the Mode of Action and Current Use of Petroleum Distilled Spray Oils. In. Pesticides in the Modern World - Pesticides Use and Management. Eds. M. Stoytcheva, InTech pub. Rijeka, Croatia, 119-136. doi: 10.5772/20394.

5. Camarda A., Pugliese N., Bevilacqua A., Circella E., Gradoni L., George D., Sparagano O., Giangaspero A. 2018. Efficacy of a novel neem oil formulation $\left(\mathrm{RP} 03^{\mathrm{rm}}\right)$ to control the poultry red mite Dermanyssus gallinae. Medical and Veterinary Entomology, 32, 3, 290-297. doi: 10.1111/mve.12296. 
6. Guimaraes J.H., Tucci E.C. 1992. Evaluation of mineral oil in the control of Dermanyssus gallinae (De Geer, 1778) (Acari, Dermanyssidae) in field and laboratory conditions. Revista Brasileira de Entomologia, 36,859-862.

7. Kang, J., Hossain, M. A., Jeong, J., Park, H., Kim, J. H., Kang, M. S., Kwon, Y. K., Kim, Y. S., Park, S. W. 2020. Application of carbon dioxide as a novel approach to eradicate poultry red mites. Journal of Veterinary Science, 21, 2, e37. doi:10.4142/jvs.2020.21.e37.

8. Maurer V., Baumgartner J. 1992. Temperature influence on life table statistics of the chicken mite Dermanyssus gallinae (Acari: Dermanyssidae). Experimental and Apply Acarology, 15, 1, 27-40.

9. Maurer V., Perler E., Heckendorn F. 2009. In vitro efficacies of oils, silicas and plant preparations against the poultry red mite Dermanyssus gallinae. Experimental and Apply Acarology, 48, 1-2, 31-41. doi:10.1007/s10493009-9254-2.

10. Nordenfors H, Höglund J., Uggla A. 1999. Effects of temperature and humidity on oviposition, molting and longevity of Dermanyssus gallinae (Acari: Dermanyssidae). Journal of Medical Entomology, 36, 1, 68-72. doi: 10.1093/jmedent/36.1.68.

11. Nordenfors H. 2000. Epidemiology and Control of the Poultry Red Mite, Dermanyssus gallinae. Doctoral thesis, Swedish University of Agricultural Sciences, Uppsala.

12. Oyamada K., Murai T. 2013. Effect of fumigation of high concentration carbon dioxide on two spotted spider mite, Tetranychus urticae Koch (Acari: Tetranychidae) and strawberry runner plant. Japanese Journal of Applied Entomology and Zoology, 57, 4, 249-256. doi: 10.1303/jjaez.2013.249.

13. Pavlićević A., Pavlović I., Dotlić M. 2007. A contribution to information on starvation survival capacity of poultry red mite Dermanyssus gallinae. Lucrari Stiintifice Medicina Veterinara 50, 9, 485-491.

14. Pavlićević A., Ratajac R., Dotlić M., Stojanov I., Pavlović I. 2017. An innovative formulation of paraffin and silicone oils for the control of the red poultry mite (Dermanyssus gallinae) -examination of the efficiency under laboratory conditions. Archives of Veterinary Medicine, 10, 2, 63-79. doi: 10.46784/e-avm.v10i2.74.

15. Pavlićević A., Ratajac R., Horvatek Tomić D., Stojanov I., Pavlović I. 2018. Dermanyssus gallinae eradication approach - application of inert compounds and integral animal health protection. Arhiv veterinarske medicine, 11, 1, 3 - 15. doi: 10.46784/e-avm.v11i1.12.

16. Pavlicevic A, Pavlovic I., Davidovic B., Ratajac R. 2019a. Clinical Examination of the Control Red Chicken Mites Dermanyssus gallinae. Scientific Papers: Animal Science and Biotechnologies, 52, 1, 105-115. 
17. Pavlićević A., Ratajac R., Stojanov I., Pavlović I. 2019b. An example of rational Dermanyssus gallinae control - Pulcap. Archives of Veterinary Medicine, 12, 1, 71 - 85. doi: 10.46784/e-avm.v12i1.39.

18. Pavlicevic A., Pavlovic I. 2020. Pulcap in the control of Dermanyssus gallinae, current clinical findings. In: Proceedings of XX International Conference Poultry Production in Russia and in the World. Present State, Dynamics of Development, Prospective Inovations. Sergiyev Posad, Moscow Region, Russia, 14-16.10.2020, 663-664.

19. Pritchard J., Kuster T., Sparagano O., Tomley F. 2015. Understanding the biology and control of the poultry red mite Dermanyssus gallinae: a review. Avian Patology, 44, 3, 143-153. doi: 10.1080/03079457.2015.1030589.

20. Suzuki, T., Wang C.-H., Gotoh T., Amano H., Ohyama K. 2015. Deoxidantinduced anoxia as a physical measure for controlling spider mites (Acari: Tetranychidae). Experimental and Applied Acarology, 65, 3, 293- 305. doi: 10.1007/s10493-015-9881-8.

21. Thomas E, Chiquet M, Sander B, Zschiesche E, Flochlay AS. 2017. Field efficacy and safety of fluralaner solution for administration in drinking water for the treatment of poultry red mite (Dermanyssus gallinae) infestations in commercial flocks in Europe. Parasites and Vectors, 10, 1, 457. doi: 10.1186/s13071-017-2390-3.

22. Tucci E.C., Prado A.P., Araúlo R.P. 2008. Thermal requirements of Dermanyssus gallinae (De Geer, 1778) (Acari: Dermanyssidae). Revista Brasiliera de Parasitologia Veterinary, 17, 2, 67-72. doi: 10.1590/S198429612008000200002.

23. Tucci E.C., Prado A.P., Araúlo R.P. 2009. Influência do jejum sobre a fecundidade de Dermanyssus gallinae (De Geer, 1778) (Acari, Dermanyssidae). Arquivos Instituto Biológico São Paulo, 76, 1, 23-26. doi: 10.1590/18081657v76p0232009.

24. Van Emous R. 2005. Wage war against the red mite. Poultry International, 44, 26-33.

25. Wood, H.P. 1917. The chicken mite: its life history and habits. Bulletin of the United States Department of Agriculture, 553.

Received: 16.05.2021.

Accepted: 21.06.2021. 